\title{
Decision tree for selection of suitable cultivation parameters for mammalian cell culture processes
}

\author{
Ralf Pörtner ${ }^{1 *}$, Simon Kern ${ }^{1}$, Dieter Eibl ${ }^{2}$ \\ From 24th European Society for Animal Cell Technology (ESACT) Meeting: C2P2: Cells, Culture, Patients, Products \\ Barcelona, Spain. 31 May - 3 June 2015
}

\begin{abstract}
Background
Development of bioprocesses for mammalian cells has to deal with different bioreactor types and scales. Bio-reactors might be intended for seed train and production, research, process development, validation or transfer purposes. During these activities, not only the problem of up- and downscaling might lead to failure of repro-ducibility, but also the use of different bioreactor geometries and operation conditions. In such cases, the criteria for bioreactor design and process transfer should be re-evaluated in order to avoid an erroneous transfer of cultivation parameters.
\end{abstract}

\section{Concept}

For selection of process conditions several questions can be asked:

- Type and scale of the intended cultivation system

- Which data are required (cell specific parameters, specific data for the cultivation system)?

- Are appropriate data e.g. for cell growth, substrate uptake, medium composition available?

- For which cultivation systems have these data been determined?

- Are data on power input, mixing time, oxygen transfer etc. available?

- Which methods can be used to determine or estimate the above mentioned parameters?

For selection and evaluation of suitable cultivation parameters a decision tree (Figure 1) has been formulated to provide a guideline for design of mammalian cell culture processes. References for process transfer

\footnotetext{
* Correspondence: poertner@tuhh.de

1 Institute of Bioprocess and Biosystems Engineering, Hamburg University of Technology, Hamburg, D-21073, Germany

Full list of author information is available at the end of the article
}

strategies are given for the following cases:

- Scale similar and power imput similar: [1-3]

- Scale similar and power imput similar: [4-6]

- Scale up and power imput similar: $[7,8]$

- Scale up and power imput similar: $[4,9,10]$

\section{Authors' details}

'Institute of Bioprocess and Biosystems Engineering, Hamburg University of Technology, Hamburg, D-21073, Germany. ${ }^{2}$ Institute of Biotechnology, Biochemical Engineering and Cell Cultivation Technique, Zurich University of Applied Sciences, 8820 Wädenswil, Switzerland.

Published: 14 December 2015

\section{References}

1. Platas OB, Jandt U, PhanLd M, Villanueva ME, Schaletzky M, Rath A, Freund S, Reichl U, Skerhutt E, Scholz S, Noll ThSandig V, Pörtner R, Zeng AP: Evaluation of criteria for bioreactor comparison and operation standardisation for mammalian cell culture. EngLifeSci 2012, 12(5):518-528.

2. Minow B, Tschoepe S, Regner A, Populin M, Reiser S, Noack C, Neubauer : Biological performance of two different $1000 \mathrm{~L}$ single-use bioreactors applying a simple transfer approach. Eng Life Sci 2014, 14(3):283-291.

3. Minow B, Seidemann J, Tschoepe S, Gloeckner A, Neubauer P: Harmonization and characterization of different single-use bioreactors adopting a new sparger design. Eng Life Sci 2014, 14(3):272-282.

4. Kaiser St, Eibl D: Dynamic Single-Use Bioreactors Used in Modern Literand m3- Scale. Biotechnological Processes: Engineering Characteristics and Scaling Up.AdvBiochemEngBiotechnol 2014, 138:1-44.

5. Greller G, Eibl D: Single-use wave-mixed versus stirred bioreactors for insect-cell/BEVS-based protein expression at benchtop scale. Eng Life Sci 2014, 14(3):264-271.

6. Goedde A, Reiser S, Russ K, Krüger O, Cayli A, Wagner R: Characterisation of two Single-Use Bioreactors for Mammalian Cell Culture Processes. [http://rentschler.de/fileadmin/Downloads/Poster/Rentschler-PosterBMD_Summit-2010.pdf], Oktober 2010.

7. Xing Z, Kenty BM, Li ZJ, Lee SS: Scale-up analysis for a CHO cell culture process in large-scale bioreactors. BiotechnolBioeng 2009, 103(4):733-746.

8. Yang JD, Lu C, Stasny B, Henley J, Guinto W, Gonzalez C, et al: Fed-batch bioreactor process scale-up from 3-L to 2,500-L scale for monoclonal antibody production from cell culture. BiotechnolBioeng 2007, 98(1):141-154

9. Minow B, Rogge P, Thompson K: Implementing a Fully Disposable MAb Manufacturing Facility. 2012 [http://www.bioprocessintl.com/ manufacturing/antibody-non-antibody/implementing-a-fully-disposablemab-manufacturing-facility-331156/]. 


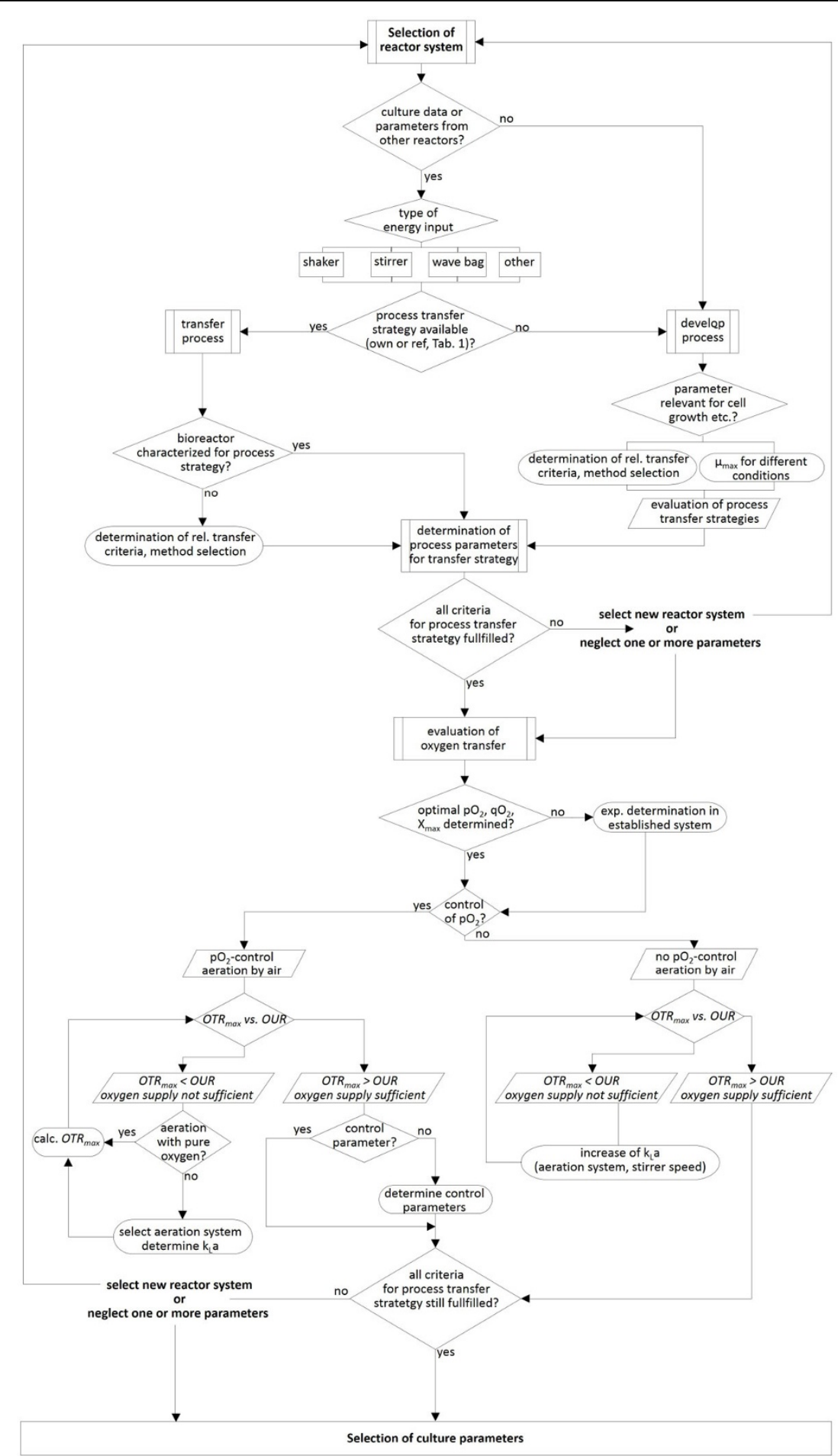

Figure 1 Decision tree for selection of suitable cultivation parameters $\mu$ - growth rate, OTR - oxygen transfer rate, OUR - oxygen uptake rate, $\mathrm{k}_{\mathrm{L}} \mathrm{a}$ - volume specific mass transfer coefficient.

10. Minow B: Fast Track API Manufacturing in a 1000-L Single Use Facility Facilitating a Platform Process and a Simplified Scale-up Approach. JAACT 2012, Nagoya, Japan 2012, 28. November 2012.
doi:10.1186/1753-6561-9-S9-P45

Cite this article as: Pörtner et al: Decision tree for selection of suitable cultivation parameters for mammalian cell culture processes. BMC Proceedings 2015 9(Suppl 9):P45. 